\title{
PENGARUH FRAKSI EKSTRAK DAUN BABADOTAN (Ageratum conyzoides) TERHADAP PERTUMBUHAN DAN SPORULASI Colletotrichum capsici SECARA IN VITRO
}

\author{
Shintya Wulandari, Titik Nur Aeny \& Efri \\ Jurusan Agroteknologi, Fakultas Pertanian, Universitas Lampung \\ Jl. Prof. Dr. Soemantri Brodjonegoro No. 1 Bandar Lampung 35145
}

\begin{abstract}
ABSTRAK
Penyakit antraknosa yang disebabkan oleh Colletotrichum capsici merupakan salah satu penyakit penting pada tanaman cabai. Salah satu cara pengendalian penyakit antraknosa yang ramah lingkungan adalah penggunaan fungisida nabati atau fungisida yang berasal dari ekstrak daun atau bagian-bagian tanaman lain. Penelitian ini bertujuan untuk mengetahui efektivitas ekstrak daun babadotan yang difraksinasi dengan pelarut air, metanol, etil asetat dan n-heksana dalam menekan pertumbuhan dan sporulasi $C$. capsici secara in vitro. Penelitian ini dilakukan di Laboratorium Penyakit Tanaman, Fakultas Pertanian, Universitas Lampung pada bulan September sampai dengan Desember 2014. Rancangan perlakuan yang digunakan adalah rancangan acak lengkap, dengan 6 perlakuan dan 5 ulangan. Keenam perlakuan tersebut yaitu perlakuan tanpa menggunakan ekstrak, ekstrak tanaman uji dengan pelarut air, metanol, etil asetat dan n-heksana serta fungisida sintetik berbahan aktif propineb $70 \%$. Hasil penelitian menunjukkan bahwa fraksi ekstrak daun babadotan dengan pelarut metanol menunjukkan hasil yang paling baik dalam menghambat pertumbuhan dan sporulasi $C$. capsici secara in vitro. Namun, keefektivan fraksi ekstrak tersebut lebih rendah dibandingkan dengan fungisida sintetik berbahan aktif propineb $70 \%$.
\end{abstract}

Kata kunci: Babadotan, Colletotrichum capsici, ekstrak daun, fungisida nabati

\section{PENDAHULUAN}

Cabai merah (Capsicum annum L.) merupakan salah satu komoditas hortikultura yang penting di Indonesia. Sebagian buah cabai digunakan sebagai konsumsi rumah tangga untuk bumbu masak atau bahan masakan. Selain itu buah cabai dapat dimanfaatkan sebagai bahan ramuan obat tradisional (Prajnata, 2003). Salah satu penyakit penting pada tanaman cabai merah adalah penyakit antraknosa. Penyebab penyakit antraknosa salah satunya adalah Colletotrichum capsici (Semangun, 2007). Keparahan penyakit antraknosa di lapang mencapai $40 \%$ dan dapat menurunkan hasil mencapai $65 \%$ sehingga menurunkan pendapatan petani (Herwidyarti dkk., 2013).

Salah satu pengendalian yang biasa dilakukan adalah dengan aplikasi fungsida sintetik secara intensif. Penggunaan fungisida sintetik yang kurang bijaksana dapat menimbulkan dampak negatif (Kardinan, 2011). Upaya untuk meminimalisir dampak negatif dari penggunaan fungisida sintetik adalah dengan aplikasi fungisida nabati. Pada daun babadotan terdapat senyawa saponin, flavonoid, polifenol, dan minyak atsiri (Asmaliyah dkk., 2010). Penelitian Khan \& Nasreen (2010) menunjukkan senyawa alkaloid, saponin dan tanin bersifat antifungi terhadap C. capsici, Rhizoctonia solani dan Fusarium oxysporum. Oleh sebab itu perlu dilakukan kajian ilmiah untuk mengetahui potensi daun sirih merah, babadotan, dan gulma siam sebagai fungisida nabati dalam menekan pertumbuhan dan sporulasi $C$. capsici secara in vitro.

\section{BAHAN DAN METODE}

Penelitian ini dilaksanakan pada bulan September sampai dengan Desember 2014. Percobaan dilakukan di Laboratorium Penyakit Tumbuhan Fakultas Pertanian Universitas Lampung. Bahan-bahan yang digunakan dalam percobaan ini adalah daun babadotan, biakan Colletotrichum capsici, air steril, metanol teknis, etil asetat teknis, n-heksana teknis, klorok $1 \%$, fungisida berbahan aktif propineb $70 \%$, arang aktif, aquades, surfaktan, dan media PSA (potato succrose agar). Alat yang digunakan diantaranya alat fraksinasi sederhana (Gambar 1) mistar, gelas ukur, handpomp, cawan petri, labu erlenmeyer, autoklaf, alumunium foil, plastik tahan panas, tisu, nampan plastik, plastik wrap, mikropipet, bunsen, cutter, pinset, ose, haemocytometer, mikroskop majemuk, kaca preparat, bor gabus, dan drugalski.

Percobaan terdapat enam perlakuan dan lima ulangan. Perlakuan terdiri dari kontrol/ tanpa menggunakan ekstrak (P0), fraksi ekstrak daun 


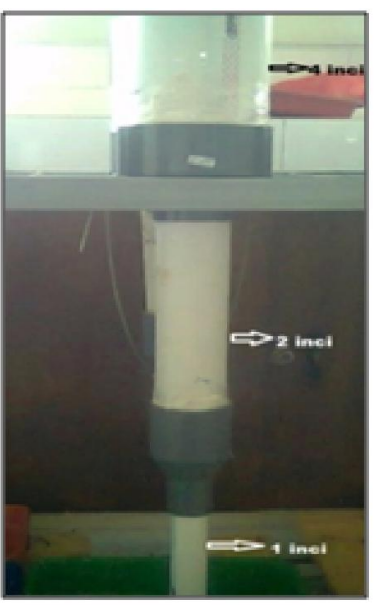

Gambar 1. Alat fraksinasi sederhana

babadotan dengan pelarut air (P1), fraksi ekstrak daun babadotan dengan pelarut metanol (P2), fraksi ekstrak daun babadotan dengan pelarut etil asetat (P3), fraksi ekstrak daun babadotan dengan pelarut n-heksana (P4) dan perlakuan dengan fungisida propineb $70 \%$ (P5). Fraksi ekstrak daun babadotan digunakan dengan konsentrasi $1000 \mathrm{ppm}$ dan fungisida sintetik berbahan aktif propineb $70 \%$ dengan dosis $1 \mathrm{~g} / \mathrm{l}$. Percobaan disusun menggunakan rancangan acak lengkap (RAL), dan data hasil pengamatan dianalisis dengan sidik ragam (Anova).

Daun babadotan yang segar dan tidak berpenyakit sebanyak $100 \mathrm{~g}$ dicuci dan dikering anginkan. Setelah itu diblender dengan air sebanyak 1 liter. Setelah halus ekstrak daun babadotan dituang ke dalam alat fraksinasi sederhana kemudian hasil penyaringan ditampung di dalam nampan dan dikering anginkan. Hasil yang diperoleh tersebut merupakan fraksi ekstrak daun babadotan dengan pelarut air. Ekstrak kasar yang tertinggal di alat fraksinasi sedrhana selanjutnya dituang pelarut kedua (metanol teknis) sebanyak $900 \mathrm{ml}$. Hasil yang diperoleh ditampung di dalam nampan dan dikering anginkan. Hasil tersebut merupakan fraksi ekstrak daun babadotan dengan pelarut metanol. Dilakukan hal yang sama untuk pelarut ketiga (etil asetat) dan keempat (nheksana).

Pada penyiapan isolat $C$. capsici, isolat $C$. capsici diperoleh dari buah cabi merah yang bergejala antraknosa. Bagian antara yang sehat dan sakit pada buah cabai merah diisolasi di media PSA. Pada penyiapan media uji, 1 liter media PSA dibutuhkan kentang $200 \mathrm{~g}$, gula $20 \mathrm{~g}$, agar batang $20 \mathrm{~g}$ dan aquades 1 liter. Kentang direbus dengan aquades 1 liter. Sari kentang yang diperoleh dicampur dengan agar batang dan gula. Setelah itu media diautoklaf selama \pm 20 menit pada suhu $121^{\circ} \mathrm{C}$ dengan tekanan 1atm. Dimasukkan ekstrak daun babadotan pada setiap fraksi ke dalam erlenmeyer sebanyak $100 \mathrm{mg}$ dan dicampurkan dengan surfaktan sebanyak 100 mikromili, setelah homogen media PSA yang telah steril dimasukan ke dalam erlenmeyer sebanyak $100 \mathrm{ml}$.

Peubah yang diamati adalah diameter koloni dan kerapatan spora C. capsici. Pengamatan diameter koloni jamur dilakukan untuk mengetahui pertumbuhan vegetatif jamur. Pengukuran dilakukan pada hari ke 2 sampai hari ke 9 setelah inokulasi. Penghitungan kerapatan spora dilakukan pada hari ke-14 setelah inokulasi menggunakan alat haemocytometer. Pertama, biakan jamur digenangi dengan aquades sebanyak 10 ml. Kemudian aquades diratakan pada permukaan media sehingga semua spora terlepas dari permukaan media dan dimasukkan ke dalam tabung reaksi yang berisi $90 \mathrm{ml}$ aquades lalu dihomogenkan menggunakan rotamixer. Suspensi yang diperoleh digunakan sebagai pengenceran awal $\left(10^{\circ}\right)$. Kemudian diambil $1 \mathrm{ml}$ suspensi spora dengan menggunakan mikropipet lalu diletakkan pada kaca preparat haemocytometer hingga suspensi mengalir ke bawah kaca objek dan memenuhi ruang hitung pada kaca preparat haemocytometer. Kerapatan spora dihitung dengan menggunakan rumus Gabriel dan Riyatno,1989 dalam Herlinda dkk. (2006) :

$$
S=\frac{t}{(n \times 0,25)} \times 10^{6}
$$

\section{Keterangan:}

$\mathrm{S}$ = jumlah spora per ml larutan

$\mathrm{t} \quad=$ jumlah total spora di kotak sampel yang diamati $0,25=$ konstanta (faktor koreksi penggunaan kotak sampel skala kecil pada haemocytometer)

$\mathrm{n} \quad=$ jumlah kotak sampel yang diamati

\section{HASIL DAN PEMBAHASAN}

Dari hasil uji F diketahui bahwa perlakuan fraksi ekstrak daun babadotan berpengaruh nyata terhadap pertumbuhan dan sporulasi Colletotrichum capsici. Hasil uji lanjut dengan BNT (Tabel 1) menunjukkan bahwa fraksi ekstrak daun babadotan dengan pelarut metanol mempunyai pengaruh yang lebih besar dibandingkan dengan pengaruh ekstrak daun babadotan dengan pelarut air, etil asetat dan n-heksana. Fraksi ekstrak daun babadotan dengan pelarut metanol dan nheksana mampu menghambat pertumbuhan C. capsici secara konsisten, meskipun efektivitas kedua fraksi ekstrak tersebut masih lebih rendah dibandingkan 
Tabel 1. Pengaruh fraksi ekstrak daun babadotan terhadap diameter koloni C. capsici.

\begin{tabular}{|c|c|c|c|c|c|c|c|c|}
\hline \multirow[t]{2}{*}{ Perlakuan (ekstrak) } & \multicolumn{8}{|c|}{ Diameter koloni $(\mathrm{cm})$ pada } \\
\hline & $2 \mathrm{hsi}$ & $3 \mathrm{hsi}$ & $4 \mathrm{hsi}$ & $5 \mathrm{hsi}$ & $6 \mathrm{hsi}$ & $7 \mathrm{hsi}$ & $8 \mathrm{hsi}$ & $9 \mathrm{hsi}$ \\
\hline Kontrol & $1,236 \mathrm{~b}$ & $1,662 \mathrm{c}$ & $2,086 b$ & $2,562 b$ & $2,990 \mathrm{~b}$ & $3,366 b$ & $3,766 b$ & $4,140 \mathrm{~b}$ \\
\hline B + air & $1,342 \mathrm{a}$ & $1,836 \mathrm{~b}$ & $2,222 b$ & $2,676 b$ & $3,126 b$ & $3,466 b$ & $3,810 \mathrm{~b}$ & $4,110 \mathrm{~b}$ \\
\hline $\mathrm{B}+$ metanol & $1,036 \mathrm{c}$ & $1,366 \mathrm{~d}$ & $1,656 \mathrm{c}$ & $1,946 \mathrm{~d}$ & $2,254 \mathrm{~d}$ & $2,556 \mathrm{~d}$ & $2,870 \mathrm{~d}$ & $3,180 \mathrm{~d}$ \\
\hline $\mathrm{B}+$ etil asetat & $1,432 \mathrm{a}$ & $2,066 a$ & $2,798 \mathrm{a}$ & $3,440 \mathrm{a}$ & $4,020 \mathrm{a}$ & $4,610 \mathrm{a}$ & $5,216 \mathrm{a}$ & $5,680 \mathrm{a}$ \\
\hline $\mathrm{B}+\mathrm{n}$-heksana & $0,966 \mathrm{c}$ & $1,356 \mathrm{~d}$ & $1,762 \mathrm{c}$ & $2,180 \mathrm{c}$ & $2,526 \mathrm{c}$ & $2,900 \mathrm{c}$ & $3,246 \mathrm{c}$ & $3,532 \mathrm{c}$ \\
\hline Propineb $70 \%$ & $0,000 \mathrm{~d}$ & $0,000 \mathrm{e}$ & $0,000 \mathrm{~d}$ & $0,000 \mathrm{e}$ & $0,000 \mathrm{e}$ & $0,000 \mathrm{e}$ & $0,000 \mathrm{e}$ & $0,000 \mathrm{e}$ \\
\hline $\operatorname{Pr}<\mathrm{F}$ & 0,0001 & 0,0001 & 0,0001 & 0,0001 & 0,0001 & 0,0001 & 0,0001 & 0,0001 \\
\hline BNT & 0,005 & 0,007 & 0,015 & 0,019 & 0,018 & 0,023 & 0,025 & 0,030 \\
\hline
\end{tabular}

Keterangan: $\operatorname{Pr}<$ F $0,1=$ sangat nyata. Nilai dalam kolom yang diikuti huruf yang sama, tidak berbeda nyata menurut uji BNT pada taraf 5\%. hsi: hari setelah inokulasi. Kontrol: tanpa ekstrak. B: babadotan.

fungisida pembanding (propineb 70\%). Fraksi ekstrak daun babadotan dengan pelarut air tidak konsisten dalam menghambat C.capsici. Sebaliknya fraksi ekstrak daun babadotan dengan pelarut etil asetat dapat memacu pertumbuhan $C$. capsici.

Fraksi ekstrak daun babadotan dengan pelarut air, metanol dan n-heksana dapat menghambat sporulasi $C$. capsici. Meskipun efektivitas ketiga fraksi ekstrak tersebut masih lebih rendah dibandingkan dengan fungisida pembanding (propineb $70 \%$ ). Sebaliknya fraksi ekstrak daun babadotan dengan pelarut etil asetat dapat memacu sporulasi C. capsici (Tabel 2). Dengan demikian, ekstrak daun babadotan dengan pelarut metanol merupakan fraksi ekstrak yang efektif dalam menghambat pertumbuhan dan sporulasi $C$. capsici meskipun tidak sebaik propineb $70 \%$.

Aktivitas antifungi pada setiap fraksi ekstrak daun babadotan dapat dilihat dari pertumbuhan koloni dan sporulasi C. capsici. Semakin kecil ukuran diameter koloni $C$. capsici maka semakin besar pengaruh fraksi ekstrak daun tanaman uji terhadap pertumbuhan $C$. capsici. Begitu pula pada sporulasi, semakin sedikit kerapatan spora $C$. capsici maka semakin besar pengaruh fraksi ekstrak daun tanaman uji terhadap sporulasi C. capsici. Berdasarkan analisis data yang diperoleh menunjukkan adanya perbedaan pengaruh aktivitas antifungi pada setiap fraksi ekstrak daun tanaman uji. Perbedaan pengaruh yang terjadi pada setiap fraksi ekstrak menunjukkan adanya perbedaan bahan aktif yang terlarut dari hasil fraksinasi setiap pelarut.

Kandungan kimia dalam daun babadotan antara lain minyak atsiri, tanin (Utami, 2008), alkaloid, flavonoid, tanin, saponin, steroid, terpenoid, dan fenol (Amadi dkk., 2012). Menurut Irawan (2010) pelarut metanol memiliki
Tabel 2. Pengaruh fraksi ekstrak daun babadotan terhadap jumlah spora $\mathrm{ml}^{-1}$ C.capsici pada hari ke-14 hsi.

\begin{tabular}{lc}
\hline Perlakuan (ekstrak) & $\begin{array}{c}\text { Kerapatan spora } \\
\text { (jumlah spora ml } \mathrm{H}^{-1} \text { ) }\end{array}$ \\
\hline Kontrol & $6,56 \times 10^{6} \mathrm{~b}$ \\
B + air & $5,33 \times 10^{6} \mathrm{c}$ \\
B + metanol & $2,34 \times 10^{6} \mathrm{~d}$ \\
B + etil asetat & $7,78 \times 10^{6} \mathrm{a}$ \\
B + n-heksana & $4,90 \times 10^{6} \mathrm{c}$ \\
Propineb 70\% & $0,00 \times 10^{6} \mathrm{e}$ \\
\hline Pr $<$ F & 0,0001 \\
\hline BNT & 0,01 \\
\hline
\end{tabular}

Keterangan: $\operatorname{Pr}<$ F 0,1 = sangat nyata. Nilai dalam kolom yang diikuti huruf yang sama, tidak berbeda nyata menurut uji BNT pada taraf 5\%. hsi: hari setelah inokulasi. Kontrol: tanpa ekstrak. B: babadotan.

kemampuan ekstraktif yang paling tinggi dibandingkan dengan pelarut etil asetat dan n-heksana. Menurut Afolabi dkk. (2007) pada ekstrak daun C. odorata dengan pelarut metanol tersari senyawa alkaloid dan tanin. Berdasarkan penelitian Yuhernita \& Juniarti (2011) tentang analisis senyawa metabolit sekunder ekstrak metanol daun surian tersari senyawa alkaloid dan flavonoid. Penelitian Irawan (2010) melaporkan pada ekstrak sirih merah dengan pelarut metanol tersari senyawa alkaloid, saponin, dan tanin. Pada fraksi ekstrak sirih merah, babadotan, dan gulma siam dengan pelarut metanol diduga tersari senyawa polar antara lain alkaloid, flavonoid, tanin, dan saponin. Senyawasenyawa yang diduga terlarut dalam fraksi ekstrak 
metanol antara lain alkaloid, flavonoid, tanin, dan saponin. Beberapa penelitian telah melaporkan senyawa-senyawa tersebut merupakan senyawa aktif yang berperan sebagai antifungi. Khan \& Nasreen (2010) melaporkan hasil penelitian tentang aktivitas antifungi ekstrak metanol dari daun Datura metel terdapat senyawa alkaloid dan saponin. Selain itu ekstrak metanol dari daun Lawsonia inermis terdapat senyawa flavonoid dan tanin. Kedua ekstrak tersebut dapat menghambat pertumbuhan C. capsici, Rhizoctonia solani, dan Fusarium oxysporum. Penelitian Hussin dkk. (2009) menunjukkan senyawa flavonoid dari ekstrak metanol daun Barringtonia racemosa (Putat kampung) dapat menghambat pertumbuhan Fusarium sp. (53,45\%), Ganoderma lucidum (34,57\%) dan Aspergillus spp. (32,27\%). Abad dkk. (2007) mengatakan isolasi senyawa alkaloid dari ekstrak Haplophyllum sieversii dapat menghambat pertumbuhan Colletotrichum spp. Menurut Arif dkk. (2009) saponin menghambat pertumbuhan patogen dengan meknisme merusak dinding sel patogen tersebut.

Tabel 3. Pendugaan mekanisme kerja bahan aktif ekstrak tanaman uji.

\begin{tabular}{ll}
\hline $\begin{array}{l}\text { Mekanisme } \\
\text { Kerja }\end{array}$ & Kriteria \\
\hline Fungistatik & $\begin{array}{l}\text { Jika rasio diameter koloni } \\
\text { semakin kecil dan sebanding } \\
\text { dengan rasio kerapatan spora. }\end{array}$ \\
Fungitoksik & $\begin{array}{l}\text { Jika rasio diameter koloni dan } \\
\text { kerapatan spora mendekati nol. }\end{array}$ \\
Anti & Jika rasio kerapatan spora lebih \\
Sporulan & kecil dari rasio koloni. \\
\hline
\end{tabular}

Sumber: Efri, 2015 (Komunikasi Pribadi)
Pendugaan mekanisme kerja bahan aktif fraksi ekstrak daun sirih merah, babadotan dan gulma siam terhadap pertumbuhan dan sporulasi $C$. capsici pada setiap perlakuan dilakukan berdasarkan rasio diameter koloni $C$. capsici perlakuan ekstrak tanaman dengan kontrol dan kerapatan spora perlakuan ekstrak tanaman dengan kontrol. Semakin kecil nilai rasio maka pengaruh perlakuan terhadap pertumbuhan diameter koloni ataupun kerapatan spora semakin besar (Tabel 3).

Pada fraksi ekstrak daun babadotan memilki mekanisme kerja bahan aktif tanaman yang berbeda pada setiap perlakuan. Kontrol digunakan sebagai pembanding dalam menetukan mekanisme kerja bahan aktif sebagai fungisida terhadap fraksi ekstrak daun babadotan dengan pelarut air, metanol, etil asetat, nheksana dan propineb $70 \%$. Fraksi ekstrak daun babadotan dengan pelarut air, metanol dan n-heksana memiliki kriteria rasio diameter koloni semakin kecil dan sebanding dengan rasio kerapatan spora $C$. capsici. Dengan demikian bahan aktif ketiga fraksi ekstrak tersebut memiliki mekanisme kerja fungistatik. Fraksi ekstrak daun babadotan dengan pelarut etil asetat tidak berpotensi sebagai fungisida nabati dilihat dari presentase diameter koloni dan sporulasi C. capsici. Propineb 70\% memiliki kriteria rasio diameter koloni dan kerapatan spora mendekati nol. Dengan demikian bahan aktif propineb $70 \%$ memiliki mekanisme kerja fungitoksik (Tabel 4).

\section{KESIMPULAN}

Berdasarkan penelitaian yang telah dilakukan dapat disimpulkan bahwa setiap fraksi ekstrak daun babadotan memiliki efektivitas yang berbeda dalam menekan pertumbuhan dan sprulasi $C$. capsici secara in vitro. Fraksi ekstrak daun babadotan dengan pelarut

Tabel 4. Perbandingan diameter koloni $C$. capsici dengan kerapatan spora pada percobaan fraksi ekstrak daun babadotan.

\begin{tabular}{lccc}
\hline Perlakuan & $\begin{array}{c}\text { Diameter Koloni } \\
\text { C. capsici }(\%)\end{array}$ & $\begin{array}{c}\text { Kerapatan Spora } \\
\text { C. capsici }(\%)\end{array}$ & $\begin{array}{c}\text { Mekanisme Kerja Bahan } \\
\text { Aktif Tanaman }\end{array}$ \\
\hline Kontrol & 100 & 100 & \\
B + air & 99,28 & 81,25 & Fungistatik \\
B + metanol & 76,81 & 35,67 & Fungistatik \\
B + etil asetat & 137,20 & 118,60 & - \\
B + n-heksana & 85,27 & 74,70 & Fungistatik \\
Propineb 70\% & 0 & 0 & Fungitoksik \\
\hline
\end{tabular}

Keterangan: proporsi pertumbuhan/kerapatan spora dibandingkan dengan kontrol. Kontrol: tanpa ekstrak. B: babadotan. 
metanol efektif dalam menghambat pertumbuhan dan sporulasi $C$. capsici secara in vitro. Fraksi ekstrak daun babadotan dengan pelarut metanol keefektivannya lebih rendah dibandingkan dengan fungisida sintetik propineb $70 \%$.

\section{DAFTAR PUSTAKA}

Abad, M.J., Ansuategui, M., \& Bermejo, P. 2007. Active antifungal substances from natural sources. Arkivoc Journal 7(vii) : 116-145.

Afolabi, C.A., Ibukun, E.O., \& Ologe, I.A. 2007. Phytochemical constituents and antioxidant properties of extracts from the leaves of Chromolaena odorata. Scientific Research and Essay 2(6) : 191-194.

Amadi, B.A., Duru, M.K.C., \& Agomuo, E.N. 2012. Chemical profilesof leaf, stem, root and flower of Ageratum conyzoides. Asian Journal of Plant Science and Research 2(4) : 428-432.

Arif, T., Bhosale, J.D., Kumar, N., Mandal, T.K., Bendre, R.S., Lavekar, G.S., \& Dabur, R. 2009. Natural products - antifungal agents derived from plants. Journal of Asian Natural Products Research 11(7) : 621-638.

Asmaliyah., Wati, E.E., Utami, S., Mulyadi, K., Yudhistira., \& Sari, F.W. 2010. Pengenalan Tumbuhan Penghasil Pestisida Nabati dan Pemanfaatan Secara Tradisional. Pusat Penelitian \& Pengembangan Produktivitas Hutan. Kementrian kehutanan. 58hlm.

Herlinda, S., Utama.M.D., Pujiastuti.Y., \& Suwandi. 2006. Kerapatan dan viabilitas spora Beauveria bassiana (Bals.) akibat subkultur \& pengayaan media, serta virulensinya terhadap larva Plutella xylostella (Linn.). Jurnal Hama dan Penyakit Tumbuhan Tropika 6(2) : 70-78.
Herwidyarti, K.H., Ratih, S., \& Sembodo, D.R.J. 2013. Keparahan penyakit antraknosa pada cabai (Capsicum annum L.) dan berbagai jenis gulma. Jurnal Agrotek Tropika 1(1) : 102-106.

Hussin, N. M., Muse, R., Ahmad, S., Ramli, J., Mahmood, M., Sulaiman, M.R., Shukor, M.Y.A., Rahman M.F.A., \& Aziz K. N. K. 2009. Antifungal activity of extracts and phenolic compounds from Barringtonia racemosa L. (Lecythidaceae). African Journal of Biotechnology 8 (12) : $\quad$ 2835-2842.

Irawan, C. 2010. Studi komponen bioaktif daun sirih merah. Tesis. Magister Ilmu Kimia. Universitas Indonesia. Depok.

Kardinan, A. 2011. Penggunaan pestisida nabati sebagai kearifan lokal dalam pengendalian hama dalam menuju pertanian organik. Jurnal Pengembangan Inovasi Pertanian 4 (4) : 262278.

Khan, Z.S. \& Nasreen, S. 2010. Phytochemical analysis, antifungal activity and mode of action of methanol extracts from plants against pathogens. Journal of Agricultural Technology 6(4): 793-805.

Prajnata, F. 2003. Agribisnis Cabai Hibrida. Penebar Swadaya. Jakarta. $162 \mathrm{hlm}$.

Semangun, H. 2007. Penyakit-Penyakit Tanaman Hortikultura di Indonesia Edisi Kedua. Gadjah Mada University Press. Yogyakarta. 845hlm.

Utami, P. 2008. Buku Pintar Tanaman Obat. Agromedia Pustaka. Jakarta. $95 \mathrm{hlm}$.

Yuhernita \& Juniarti. 2011. Analisis senyawa metabolit sekunder dari ekstrak metanol daun surian yang berpotensi sebagai antioksidan. Jurnal Makara Sains 15(1) : 48-52. 